\title{
Bogusław Pfeiffer, Rex et Patria. Temat władcy, narodu $i$ ojczyzny $w$ literaturze $i$ sztuce XVIII stulecia, red. Aleksandra Oszczęda, Wydawnictwo DiG, Warszawa 2012, ss. 302
}

(c) $(1) \Theta$

DOI: http://dx.doi.org/10.12775/KLIO.2014.012

М $\begin{aligned} & \text { onografia Bogusława Pfeiffera Rex et Patria. Temat wtadcy, narodu } \\ & \text { i ojczyzny w literaturze } i \text { sztuce XVIII wieku jest książka szczególną }\end{aligned}$ Ukazała się po śmierci autora, który nie miał wpływu na jej ostateczną redakcję, zmarł bowiem w trakcie wprowadzania poprawek i uwag recenzenckich. $\mathrm{Z}$ pierwszego konspektu książki wynika, że ambicją autora było pokazanie różnic między tradycyjnym ujęciem symboliki władzy a rozwiązaniami nowymi, wyraźnie zaznaczającymi się w drugiej połowie XVIII stulecia. Według ustaleń Bogusława Pfeiffera, badacza związków sztuk wizualnych ze sztuką słowa w kulturze dawnej, w XVI i XVII wieku

literatura i sztuki plastyczne oddziaływały na siebie wzajemnie, tworząc często nierozerwalną całość, natomiast w wieku XVIII, zwłaszcza w drugiej połowie, przeważają utwory pozbawione odniesień do szeroko rozumianej ikonografii (s. 7).

W całej pracy pobrzmiewa myśl, że XVIII stulecie jest w tej kwestii czasem przełomowym. Recenzowana książka stanowi kontynuację wątków podjętych we wcześniejszej rozprawie Bogusława Pfeiffera, zatytułowanej Caelum et Regnum. Studia nad symbolika państwa i wtadcy w polskiej literaturze i sztuce XVI i XVII stulecia (Zielona Góra 2002). Tytuł książki Rex et Patria nawiązuje do formuły tam przyjętej.

Publikacja zawdzięcza ostateczny kształt nie jednej, ale kilku osobom: recenzentom wydawniczym - Janinie Abramowskiej i Jakubowi Z. Lichańskiemu - Aleksandrze Oszczędzie, która nie tylko opracowała indeks i bibliografię, ale zredagowała całość, oraz Teresie Kostkiewiczowej 
i Magdalenie Górskiej ${ }^{1}$. Największa odpowiedzialność spoczęła na Aleksandrze Oszczędzie, która musiała dokonać kilku istotnych rozstrzygnięć. Informuje o tym w krótkim wprowadzeniu, zatytułowanym $O$ książce. Oszczęda porównała maszynopis z drukowanymi wcześniej artykułami Pfeiffera, które w jakiejkolwiek postaci weszły w skład książki. Wprowadziła do autorskiej wersji pewne modyfikacje, nie wnosząc jednak do tekstu głównego poprawek niezatwierdzonych przez autora. Niektóre zmiany mają charakter techniczny, należy do nich zastąpienie rozdziałów i podrozdziałów częściami, co pozwoliło uporządkować przypisy. Oszczęda zmieniła także, zgodnie z sugestią Teresy Kostkiewiczowej, tytuł ostatniej części książki. W wersji autorskiej brzmiał on następująco: Patria immortalis. Rzeczpospolita, naród, historia. Uzupełniła bibliografię oraz przypisy (głównie o pozycje sugerowane w recenzjach, ale też o najnowsze publikacje) i skorygowała oczywiste błędy i literówki, nie zaznaczając tego w tekście. Inne zmiany sygnalizowane są adnotacją w nawiasie kwadratowym. Decyzje Oszczędy wydają się słuszne, otrzymujemy uporządkowany, czytelny i sfunkcjonalizowany wywód. Książka składa się z następujących części: autorskiego Wstępu, trzech części o interesująco brzmiących tytułach (1. Pod znakiem Wettynów i Stanistawa Leszczyńskiego; 2. Stanistaw August Poniatowski; 3. Reges Martales, Respublica Immortalis. Wizerunki Rzeczypospolitej w piśmiennictwie politycznym i literaturze XVIII wieku), zestawienia prac Bogusława Pfeiffera, bibliografii (z wykazem skrótów i podziałem na rękopisy, źródła drukowane oraz opracowania), spisu ilustracji i indeksu osób. Dodatki te ułatwiają lekturę recenzowanej publikacji i przypominają postać zmarłego badacza - autora licznych prac o alegorii, alegorezie i emblemacie. $\mathrm{Na}$ okładce umieszczono reprodukcję ryciny wyobrażającej projekt przebudowy Izby Senatorskiej w Zamku Królewskim w Warszawie według Victora Louisa (1765).

Wstęp zawiera podstawowe informacje dotyczące realizowanego tematu, zakresu wykorzystanych źródeł, celu i metod pracy, a także przyjętego porządku prezentacji rozwijanych dalej zagadnień. Autor zaznaczył w nim, że interesują go zmiany zachodzące w XVIII wieku w zakresie topiki i iko-

${ }^{1}$ Autorki prac dotyczących ikonografii politycznej w dawnej Polsce, m.in. książki Polonia. Respublica. Patria. Personifikacja Polski w sztuce XVI-XVIII wieku, Wrocław 2005. 
nografii państwa i władcy oraz narodu i ojczyzny (od alegorii do paraboli, od teologii politycznej do polemiki i dyskursu, od „znikomości rad” do „skutecznego rad sposobu”). Pfeiffer deklaruje, że

obecne w jego pracy zestawienie przykładów zaczerpniętych z literatury, piśmiennictwa i ikonografii nie miało na celu nakreślenia równoległych historii literatury i sztuki (s. 25).

Zależy mu na ujęciu zjawisk pod kątem tematycznych powinowactw i pokazaniu przemian, czego konsekwencją jest przyjęcie kryterium tematycznego przy doborze tekstów. Chronologiczny i problemowy porządek prezentacji treści pozwala obserwować ewolucję form wypowiedzi i obrazów przywołanych w pracy oraz ustalić przyczyny dokonujących się zmian.

Rozprawa koncentruje się na rządach czterech królów I Rzeczypospolitej, których uczyniono jej bohaterami: dwóch Wettynów, Augusta II Mocnego i Augusta III (więcej miejsca poświęcono Augustowi II Mocnemu), Stanisława Leszczyńskiego i Stanisława Augusta Poniatowskiego. Ważne są również rozważania o ojczyźnie i narodzie (s. 17). Autora interesuje obraz władców kształtowany na potrzeby gloryfikacji i propagandy, kreowany w obrębie topiki i ikonografii władzy.

Pierwsza część książki, Pod znakiem Wettynów $i$ Stanistawa Leszczyńskiego, obejmuje trzy zagadnienia, ujęte w odrębne segmenty tekstu: Elekcja, wjazd i koronacja. Wizerunek Augusta II Mocnego jako „króla Sarmaty", Herkules Saksoński i Rzeczpospolita, Stanistaw Leszczyński - król Rzeczypospolitej, książe Lotaryngii i Baru. Rzetelnemu przedstawieniu problematyki sprzyja wykorzystanie szerokiego zakresu źródeł. Materiał egzemplifikacyjny, uwzględniony w pierwszej części monografii, składa się z literatury okolicznościowej - głównie panegirycznej - polskiej, niemieckiej i łacińskiej oraz graficznych i malarskich konkretyzacji. Autora interesuje również architektura stała i okazjonalna, opisy fet, fajerwerków i iluminacji oraz numizmaty i medale. Zajmują go także rytuały koronacyjne i strój koronacyjny, będący nośnikiem pewnej ideologii i oznaką wizerunku tego, kto go nosił. Bogusław Pfeiffer przypomina, że w czasie koronacji Stanisława Augusta Poniatowskiego towarzyszyła mu nieprzychylna aura, 
gdyż wystąpił w stroju postrzeganym jako obcy, anachroniczny, zwanym przez współczesnych „hiszpańskim”.

Z lektury książki wynika, że wizerunek Wettynów stworzony w celach propagandowych jest jednorodny i schematyczny. W przedstawieniach Sasów dominowała symbolika solarna i herkulejska, państwa polskiego pod ich rządami - nautyczna i roślinna. Aby osiągnąć właściwy efekt, twórcy niejednokrotnie sięgali po gotowe schematy ideowe i myślowe, nawiązując do wzorów gloryfikacji imperialnej i tradycyjnej topiki wychwalania władzy. Panowanie Wettynów w Polsce charakteryzuje odmienny od rodzimego styl sprawowania rządów przy jednoczesnym dostrajaniu oficjalnego wizerunku do realiów i gustu sarmackiej Rzeczypospolitej. Polonizacja odbywała się przez podkreślanie związków władcy z polską historią i tradycją oraz katolicyzmem, zamiłowanie do pompy paradnej, odwoływanie się do postaci i legendy Jana Sobieskiego oraz do antyku. Podkreślano fakt, że Sas dla Polski przyjął katolicyzm i polski strój. Autor książki zwraca uwagę na kopiowanie i zapożyczanie układów ikonograficznych z dawnych przedstawień władców (wykonany po 1697 r. miedzioryt wyobrażający postać Augusta II Mocnego odbito z tej samej płyty, którą kilka lat wcześniej wyzyskano do sporządzenia portretu Jana III Sobieskiego) oraz wykorzystywanie elementów użytych już dekoracji i architektury okazjonalnej. Gloryfikacja i heroizacja Wettynów służyła podkreślaniu politycznej wagi unii polsko-saksońskiej. Można to zauważyć już na graficznych i malarskich konkretyzacjach elekcji, które eksponują wybór króla głosem całego narodu szlacheckiego, dając wyraz pochwale jedności i demokracji szlacheckiej.

Szkicując historię symboliki solarnej, autor kieruje uwagę w stronę Francji, pokazując, że Wettyni przejęli model propagandy i środki ukształtowane na dworze wersalskim. W konkluzji fragmentu poświęconego Wettynom pojawia się myśl, że przy całej odmienności topiki i środków artykulacji właściwych literaturze i sztuce, warto zwrócić uwagę na ideowe podobieństwa występujące w obu koncepcjach gloryfikacji panującego.

Akapity poświęcone Stanisławowi Leszczyńskiemu nie są tak obszerne. Koronacja Leszczyńskiego doczekała się mniejszej liczby relacji niż jego poprzedników a ikonografia stanowiła raczej gloryfikację jego „mecenasa”, króla Szwecji Karola XII Wittelsbacha. Bardziej okazałe były obra- 
zy przedstawiające rządy Leszczyńskiego w Lotaryngii. Powstające w tym okresie portrety króla w stroju polskim miały podkreślić jego prawa do tronu Rzeczypospolitej, choć on sam po ślubie córki Marii z królem Francji nosił się wyłącznie po francusku. Jak zauważa Pfeiffer, oprócz portretów Leszczyńskiego w sukni polskiej powstają wyobrażenia oddające upodobania władcy Lotaryngii do nauk i sztuk oraz aktualne położenie banity. Skomplikowaną sytuację tułającego się władcy ilustruje jego portret w stroju pielgrzyma Jeana Baptiste’a Oudry z 1730 roku. Pfeiffer podkreśla, że na przedstawianiu króla zaważyły jego losy. Nie on sam, ale jego protektorzy decydowali o formie i treściach przedstawień związanych z walką o polską koronę. Autor książki pochyla się także nad karykaturami króla, będącymi najczęściej pokłosiem niechętnej mu propagandy. Zwraca też uwagę na portrety niekonwencjonalne, będące wyrazem dystansu portretowanego do własnej osoby.

Druga część książki w całości poświęcona jest Stanisławowi Augustowi Poniatowskiemu. Autor koncentruje się w niej na następujących kwestiach: „Szczęśliwe na tron obranie”- elekcja i koronacja; W kręgu ojczystych dziejów. Katalog królów i „znaczniejsze w historii kraju naszego dzieta i epoki”; Virtus domitor fortunae. O królu madrym i cnotliwym. I tym razem autora interesuje literacko-obrazowy dwugłos. Stanowi go dziedzina sztuk plastycznych (architektura stała i okazjonalna, malarstwo, dekoracje i wystrój wnętrz) oraz materiał literacki (utwory okolicznościowe, ody, wiersze pochwalne i gloryfikujące króla konstrukcje emblematyczne). Dzięki temu czytelnik ma szansę zobaczyć, jak różne tworzywa mogą realizować tę samą intencję.

Rozważania autora koncentrują się wokół prób realizacji programu królewskiego, zakładającego służebność sztuki i literatury wobec władcy. Wzorem poprzednich części, zaczyna je od elekcji i koronacji władcy, przechodząc następnie do projektów i wystroju reprezentacyjnych wnętrz państwowych (Zamku Warszawskiego i Pałacu Łazienkowskiego) i elementów wizualnej propagandy polskiego króla. Uwzględnia przy tym nieliczne już wtedy utwory, ujawniające właściwe sensy tylko w ścisłym związku z określonymi dziełami sztuki jako podstawowym kontekstem dla interpretacji tekstu. Autor stwierdza, że prawomocność elekcji Poniatowskiego potwierdzają wszystkie dostępne źródła. Mimo to podejmowano zabiegi propagandowe mające na celu legitymizację wyboru króla oraz podkreślenie jego 
zgodności z rodzimą tradycją. W wyobrażeniach koronacji przeważa symbolika heraldyczno-solarna, dominuje przedstawienie Poniatowskiego jako Króla-Słońce, Apollona i potomka rzymskiego cesarza Witeliusza.

Literatura stanisławowska przynosi zasadniczo dwojakie przedstawienie władcy: tradycyjne, jako boskiego pomazańca i nowe, oświeceniowe, jako mądrego cnotliwego człowieka, który został wyniesiony na tron dzięki swoim osobistym zasługom ${ }^{2}$. Autor poddaje opisowi cztery wyraźnie wyodrębniające się modele przedstawień Stanisława Augusta. Elementy tradycyjne splatają się w nich z nowoczesnymi. Obok ciągle popularnych motywów antycznych, artyści i literaci sięgają po motywy związane z historią Rzeczypospolitej, przywołując doniosłe dla Polski wydarzenia oraz postaci dawnych władców. Pierwszy model znacząco nawiązuje do sakralnego charakteru władzy królewskiej, drugi prezentuje monarchę jako mądrego, cnotliwego mecenasa i miłośnika sztuk oraz nauki. Trzeci korzysta z wzorców sarmackich i przynosi obrazy

króla-Piasta, potomka dynastii jagiellońskiej oraz panującego, będącego oświeceniowym uosobieniem „dobrego władcy” i gospodarza Kazimierza Wielkiego (s. 200).

Natomiast „moderator, oświecony monarcha chroniący naród i państwo przed zakusami nieprzyjaciół" (ibidem) to ulubione wcielenia samego króla. Chętnie prezentuje się on jako światły monarcha i mecenas sztuki oraz doświadczony przez los władca.

Część trzecia książki, pt. Reges Mortales, Respublica Immortalis. Wizerunki Rzeczypospolitej w piśmiennictwie politycznym i literaturze XVIII wieku, dotycząca wyobrażeń Rzeczypospolitej, jest najkrótsza, zmienia się także klucz lektury - w centrum uwagi znalazło się bowiem państwo. Problem, z którym zmaga się autor, jest jasny. Cały wywód skupia się na próbie przybliżenia ewolucji wizerunku Rzeczypospolitej, zachodzącej w sferze towarzyszących mu form symbolicznych i alegorycznych przy

2 Konkluzja Pfeiffera pokrywa się tu z ustaleniami Aleksandry Norkowskiej (eadem, Wizerunki wtadcy. Stanistaw August Poniatowski w poezji okolicznościowej (1764-1795), Kraków 2006, s. 308) oraz Magdaleny Górskiej (eadem, Polonia. Respublica. Patria..., s. 357). 
uwzględnieniu specyficznej sytuacji politycznej i zmieniających się mód w zakresie stylu oraz gustu artystycznego. Z rozważań badacza można wywnioskować, że podobnie jak w wyobrażeniach władców, zauważamy przenikanie się tendencji sarmackich i nowych, związanych z formacją oświeceniową. Dominuje metaforyka architektoniczna i nautyczna, popularne jest również przedstawianie państwa jako wirydarza, łączącego cechy Edenu i ogrodu zamkniętego oraz orła będącego metonimią Rzeczypospolitej.

Ostatnia część książki zawiera wiele subtelnych spostrzeżeń na temat alegorii. Autor rejestruje różnice między alegorią XVI- i XVII-wieczną a alegorią późniejszą, wskazując przykłady nowego potraktowania alegorycznego tworzywa. Obserwujemy stopniowe zanikanie iluzyjności naoczności przedstawień alegorycznych i przekształcenie alegorii w parabolę. Formy symboliczne i alegoryczne zostają sprowadzone do poziomu „zwykłych” tropów i metafor. Badacz słusznie podkreśla, że XVIII stulecie przynosi konwencjonalizację i schematyzację zastosowań personifikacji i alegorii. Alegoria przestaje być uniwersalną metodą wykładu, jej rolę przejmuje parabola, a ona sama jest stopniowo wypierana przez dyskurs, wykład i - bliską powieściowej - narrację.

Praca zyskałaby na próbie podsumowania całości i sformułowania wniosków płynących z porównania wszystkich jej części. Trudno jednak czynić z tego zarzut, gdyż książka z wiadomych względów nie została ostatecznie „domknięta” przez autora. Monografia sytuuje się w obszarze badań interdyscyplinarnych. Jej walorem jest panoramiczne ujęcie całego splotu zagadnień związanych z tematem. Zarys takiej panoramy wymagał podwójnych kompetencji oraz bardzo dobrej znajomości wytworów architektury, literatury i sztuki omawianego okresu. Zawartość wszystkich części książki stanowi istotne uzupełnienie wiedzy o sposobach przedstawienia władcy, narodu i ojczyzny w XVIII wieku. Dobrze, że osobom zaangażowanym w publikację monografii nie zabrakło determinacji, aby podjętą inicjatywę wydawniczą doprowadzić do końca. 